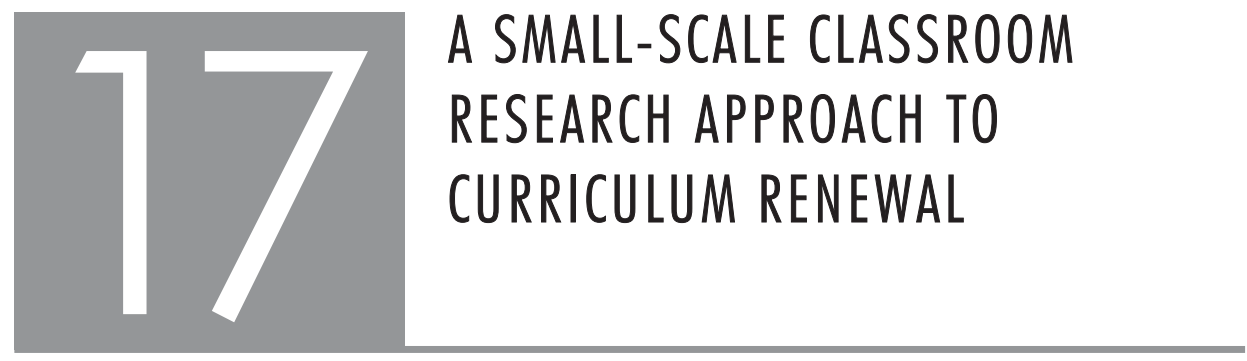

Mariette Koen

\title{
INTRODUCTION
}

Ross argues that the term curriculum can be interpreted as the organisation of desired learning experiences and that it represents a guide to lecturers of what is to be taught in specific institutions (Ross 2000:8). Challenges to organise such learning experiences in order to optimise teaching and learning opportunities are nothing new. Over the past decades universities have experienced increasing pressure from government, stakeholders and employers to design programmes that prepare graduates for today's competitive working environments. In Chapter 1 of this book, Bitzer confirms this issue by outlining the need for a systematic and scholarly approach to curriculum inquiry as a measure to address academic achievement demands and to keep curricula relevant and effective.

Stefani (2009:40) adds that the way a curriculum is designed will influence the way in which students approach their learning. It is therefore not surprising that South African teachers in higher education are constantly reminded to measure the effectiveness of their programmes in order to enhance student learning. A practical challenge is thus how to design a curriculum in the current accountability environment, one that provides students with authentic learning experiences in which they are provided with opportunities to demonstrate skills, knowledge and values required for their future professions.

Assessment, teaching and learning are key elements in a curriculum and consequently also in the pursuit of quality education. Cowdroy and Williams (2007:89) explain this close relationship by arguing that the way in which lecturers lecture will determine how their students will be assessed. In the current climate of promoting lifelong learning, scholars emphasise that assessment should not be viewed as something separate from teaching, but rather as a process aiming to develop students' ability to reflect in order to enhance their own motivation and commitment to learning (Marriott 2009:252). In fact, Race and Pickford (2007:107) maintain that assessment is "the engine which drives student learning". James, Mclnnis and Devlin (2002:11) support this notion 
by arguing that well-designed assessment tasks set clear expectations, establish a reasonable workload and provide opportunities for students to self-monitor, rehearse, practise and receive feedback.

But do students always benefit from assessment? This is one of the key questions Shay (2008:603) asks when investigating the promising role of assessment as a catalyst to enhancing student learning. One can therefore surely argue that lecturers need to investigate curriculum practices in order to reconsider assessment methods for the improvement of teaching and learning. This chapter aims at addressing this issue by referring to a small-scale curriculum inquiry as a plan of action to organise teaching and learning activities in one higher education classroom. The reported research stresses the importance of taking account of students' perceptions and it articulates how dialogic inquiry can be a tool to develop a deeper understanding of assessment aiming at pedagogical improvement.

\section{SCOPE OF THE STUDY}

Since the comprehensive research of Black and Wiliam (1998), assessment has become a central theme in the higher education environment and has been the source of various studies. A key finding in their study was that students must be able to grow from being passive receivers of knowledge to being active participants who are able to construct knowledge and take responsibility for their own learning. My studies in the field of higher education, in particular, inspired me to investigate this complex issue in a Life Skills course, in a faculty of education.

But why renew a curriculum? One could contend that designing an effective curriculum requires continuous monitoring, evaluation and modification. In this regard Carl (2009:59) states that "curriculum development is a never-ending process" as lecturers continuously aspire to improve teaching and learning. The purpose of my study was to explore assessment in a Life Skills programme in an attempt to investigate the issues that influence the quality of student learning and to formulate plans to address the said issues.

\section{CONTEXT OF THE STUDY}

Life Skills is currently one of three learning programmes (the others being Literacy and Numeracy) in the Foundation Phase and consequently one of the modules in the BEd programme at the University of the Free State. Shay and Jawitz (2005: 104) reason that assessment is considered to be a powerful influence on what and how students learn. This idea suggests that assessment of a Life Skills module should provide education students with a variety of opportunities to demonstrate their learning. It is therefore open to debate whether handwritten, one-hour examinations do indeed stimulate students to learn and develop the requisite knowledge, understanding, attitudes and skills for their future work. In this regard Beets (2009:186) explains that reflexive, foundational and practical components are necessary to empower students with the required skills to apply knowledge in both familiar and unfamiliar situations. 
In order to explore the complex issue of assessment in the Life Skills classroom, a qualitative case study design, employing semi-structured interviews and focus groups, created the opportunity to explore - through a variety of lenses - how final-year BEd Foundation Phase students dealt with assessment issues (Baxter \& Jack 2008:544; Fraenkel \& Wallen 2008:431). Although it would be interesting to know how many students felt positive or negative about assessment, the intention with this qualitative inquiry was to focus on the richness of the responses in this particular social context. It would not be possible to ascertain this by merely using only numbers and statistics (also see Basit 2003:152). This small-scale study, premised on an interpretivist paradigm, allowed me to interact closely with participants in order to gain insight into and an understanding of specifically the meaning of assessment in a particular curriculum (Henning, Van Rensburg \& Smit 2004:20).

\section{DATA-COLLECTION METHODS}

The study was conducted during the first and second semesters of 2010 and generated large quantities of data from multiple sources, such as focus groups, semi-structured interviews, open-ended questionnaires, quality-assurance documents and a literature review. As suggested by Wellington (2000:133), the data were organised systematically in order to prevent my becoming overwhelmed or losing sight of the original main research question that was formulated as: "In what way can assessment enhance learning in the Life Skills classroom?" All students attending lectures or participating in the Blackboard learning system were invited to participate in the research. Not only students but also lecturers were invited to participate in semi-structured interviews. Some lecturers had experience in Life Skills assessment while others added a new perspective to assessment in the Life Skills classroom by reflecting on their own assessment in their specific field of expertise.

Triangulation was used to capture a more complete dimension of the assessment issue. Triangulation entails the borrowing and combining of different approaches in order to confirm and improve the clarity or precision of a research finding by building a more comprehensive picture of the methods, methodological perspectives and theoretical viewpoints (Flick 2004:178; Flick 2009:444; Henning et al 2004:133; Lewis \& Ritchie 2003:275; Robson 1993:383). However, Perone and Tucker (2003:2) warn that this process should not merely entail combining data in different shapes. To me it was important that the use of triangulation should rather address different levels of the same problem and reveal varied dimensions of a particular teaching-learning situation. In this way it could contribute to supplying the pieces to a puzzle (Flick 2009:448-449). Flick (2009:444) suggests that the following guiding questions should be the points of reference for deciding to use triangulation:

- Are there different levels of information that I need to collect to understand the issue under study?

- Can I expect my participants to be exposed to several methods?

- Does my research question focus on different aspects or levels of the issue? 
Because the answers to the above questions were all 'yes', it seemed that, in this particular study, data triangulation could indeed be used productively by combining the different sets of data in order to improve understanding.

\section{ETHICAL ISSUES}

Kvale (1996:110) emphasises that ethical considerations do not belong to a specific stage of research, but are relevant throughout the entire process. Ethical considerations are therefore of the utmost importance so as to respect and honour participants. The ethical considerations in this study were based on the following aspects of the guidelines suggested by Fraenkel and Wallen (2008:63-65) and Henning et al (2004:73):

- Informed consent. Care was taken that participants fully understood the purpose of the study and were reminded in writing that participation was fully voluntary.

- Anonymity. Participants were assured that all information would be treated anonymously and that they would not be identified at any stage of the research.

- Confidentiality. Participants' right to privacy was acknowledged and all the interviews were conducted in a relationship of trust and transparency.

- Right to withdraw. Participants were assured that they would have the right to withdraw at any time during the research and would not be disadvantaged in any way.

- Ethical approval. Ethical approval was also officially obtained from the relevant department.

\section{VALIDATING THE RESEARCH}

It is well known and widely accepted that trustworthiness is of the utmost importance in any qualitative research and qualitative researchers are often criticised for their lack of rigour and are even regarded as unworthy of entering into the "magic circle of evidence" (Robson 1993:402). Lincoln and Guba (1985:294-301) demonstrated how qualitative researchers could persuade the reader to accept the findings of a study by proposing a scientific construct parallel with trustworthiness. Application of this model was done in the following way (see Table 17.1): 
CHAPTER 17 - A SMALL-SCALE CLASSROOM RESEARCH APPROACH TO CURRICULUM RENEWAL

TABLE 17.1 Application of Lincoln and Guba's model for trustworthiness

\begin{tabular}{|c|c|c|c|}
\hline \multicolumn{2}{|c|}{ Criterion } & Explanation & Application \\
\hline & & $\begin{array}{l}\text { - Credibility can be explained as confidence } \\
\text { in the truth of the findings and is regarded } \\
\text { as being parallel to internal validity (Miles } \\
\text { \& Huberman 1994:278). The focus is on } \\
\text { establishing the match between the constructed } \\
\text { realities of participants on the one hand and } \\
\text { those realities as represented by the evaluator } \\
\text { and attributed to various stakeholders on the } \\
\text { other (Crawford, Leybourne \& Arnott 2000: 1-5). } \\
\text { - Credibility can be verified by prolonged } \\
\text { engagement, persistent observation, } \\
\text { triangulation, member-checking and peer } \\
\text { examination. }\end{array}$ & $\begin{array}{l}\text { - Credibility in this study was enhanced } \\
\text { by means of triangulation and peer } \\
\text { examination. All the participants were } \\
\text { briefed about the focus of the study } \\
\text { and they expressed their willingness } \\
\text { to participate in the research. All the } \\
\text { participants gave their consent to the } \\
\text { recording of the interviews. Data were } \\
\text { provided to participants to check and } \\
\text { to verify interview data. As a verifying } \\
\text { measure, all notes were fleshed out by } \\
\text { the researcher immediately after each } \\
\text { interview had been conducted. }\end{array}$ \\
\hline & 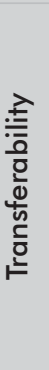 & $\begin{array}{l}\text { - Transferability signifies that the findings } \\
\text { have applicability in other contexts and can } \\
\text { be described as being parallel to external } \\
\text { validity or generalisability (Miles \& Huberman } \\
\text { 1994:279). This is relative and depends entirely } \\
\text { on the extent to which salient conditions overlap } \\
\text { or match (Crawford et al 2000: 1-5). } \\
\text { - Transferability can be established by } \\
\text { nominated sample, comparison of sample with } \\
\text { demographic data and thick description. }\end{array}$ & $\begin{array}{l}\text { - Transferability was enhanced by } \\
\text { means of a dense description of the } \\
\text { data and by maximising the range of } \\
\text { information that could be obtained } \\
\text { from and about the assessment context } \\
\text { by purposeful selection of participants. }\end{array}$ \\
\hline & & $\begin{array}{l}\text { - Dependability is parallel to reliability and is } \\
\text { likewise concerned with the stability of the data } \\
\text { over time (Miles \& Huberman 1994:278). } \\
\text { Researchers need to be able to demonstrate } \\
\text { any changes or shifts in how the inquiry was } \\
\text { conducted (Crawford et al 2000: 1-5). } \\
\text { - Dependability can be established by } \\
\text { dependability audit, dense description of } \\
\text { research methods, stepwise replication, } \\
\text { triangulation, peer examination and the } \\
\text { code-recode procedure. }\end{array}$ & $\begin{array}{l}\text { - Dependability was promoted by means } \\
\text { of an audit trail of processes, for } \\
\text { example the data-gathering process, } \\
\text { which was done by means of the } \\
\text { multiple sources of data methods and } \\
\text { data collection. The data tracing also } \\
\text { indicated that there was an ongoing } \\
\text { meta-evaluation and critical reflection } \\
\text { and allowed others to trace data } \\
\text { throughout the research process. }\end{array}$ \\
\hline & 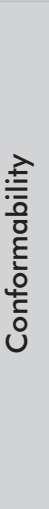 & $\begin{array}{l}\text { - Conformability is described as being parallel } \\
\text { to objectivity (Miles \& Huberman 1994:278). } \\
\text { It is the need to show that data, interpretations } \\
\text { and outcomes of inquiries are rooted in contexts } \\
\text { and persons other than the evaluator and not } \\
\text { simply figments of the evaluator's imagination. } \\
\text { All data must be traceable to their source and } \\
\text { the logic used to assemble the interpretations } \\
\text { into structurally coherent and corroborating } \\
\text { wholes must be both explicit and implicit in } \\
\text { the narrative of the case study (Crawford et al } \\
2000: 1-5 \text { ). } \\
\text { - Conformability can be verified by conformability } \\
\text { audit, triangulation, audit trail and reflexivity. }\end{array}$ & $\begin{array}{l}\text { - Conformability was similarly enhanced } \\
\text { by means of a degree of neutrality } \\
\text { where the findings were shaped by } \\
\text { the participants' perspectives and not } \\
\text { through research bias. Trustworthiness } \\
\text { was enhanced by recording interviews } \\
\text { and transcribing them verbatim so as } \\
\text { to ensure an accurate reflection of the } \\
\text { participants' views. }\end{array}$ \\
\hline
\end{tabular}


Throughout the study the aim was to construct the research soundly, to use the correct measures to conduct the research and to establish a chain of evidence both forward and backward in order to prevent subjective interpretations.

\section{CONCEPTUALISATION}

It has already been argued that assessment, teaching and learning are key elements in a curriculum and consequently also in the pursuit of quality education. Stefani (2009:40) emphasises that how we think about teaching and learning will influence how we plan assessment activities. Yet authentic assessment tasks that facilitate learning imply both knowledge of assessment and an understanding of students' needs.

Despite a number of theories that have been advanced to explain how assessment can be implemented in a curriculum, it is no simple task merely to translate this assessment knowledge into student learning. The multiplicity of assessment purposes is a problematic issue and there are no simple answers to how assessment can be used to enhance learning. The aim of this study was to explore student learning from an assessment perspective. It was hoped that an understanding could be developed of students' perspectives on assessment and that insight could be gained on ways to enhance learning in the Life Skills Education classroom. These ideas could, in turn, be helpful during the monitoring, evaluation and modification of a Life Skills curriculum.

The conceptual framework for this inquiry was mainly drawn from Race's 'spreading ripples' model of learning (Race 2001). Biggs (1999, cited in Albon 2006:103) reminds us that the starting point in designing authentic assessment strategies is to understand how learning occurs and Race's model offers a theory in which four main overlapping factors feature. It was believed that interrogating Race's learning theory and the qualitative data could provide suggestions on how the three elements, teaching, learning and assessment, could interact in a Life Skills classroom.

\section{RACE'S 'SPREADING RIPPLES' MODEL}

The underlying premise of Race's theory is that the most effective form of learning consists of the continuous effect (like the ripples on a pond) of four elements: wanting (needing), doing, feedback and digesting. Race (2001:11) argues that a human brain does not work in either a linear or pre-programmed way all the time, but rather operates at various overlapping levels when, for example, making sense of ideas. From this perspective Race $(2005: 26)$ contends that these elements are in dynamic interaction, affecting one another, and they occur more or less simultaneously (see Figure 17.1). 


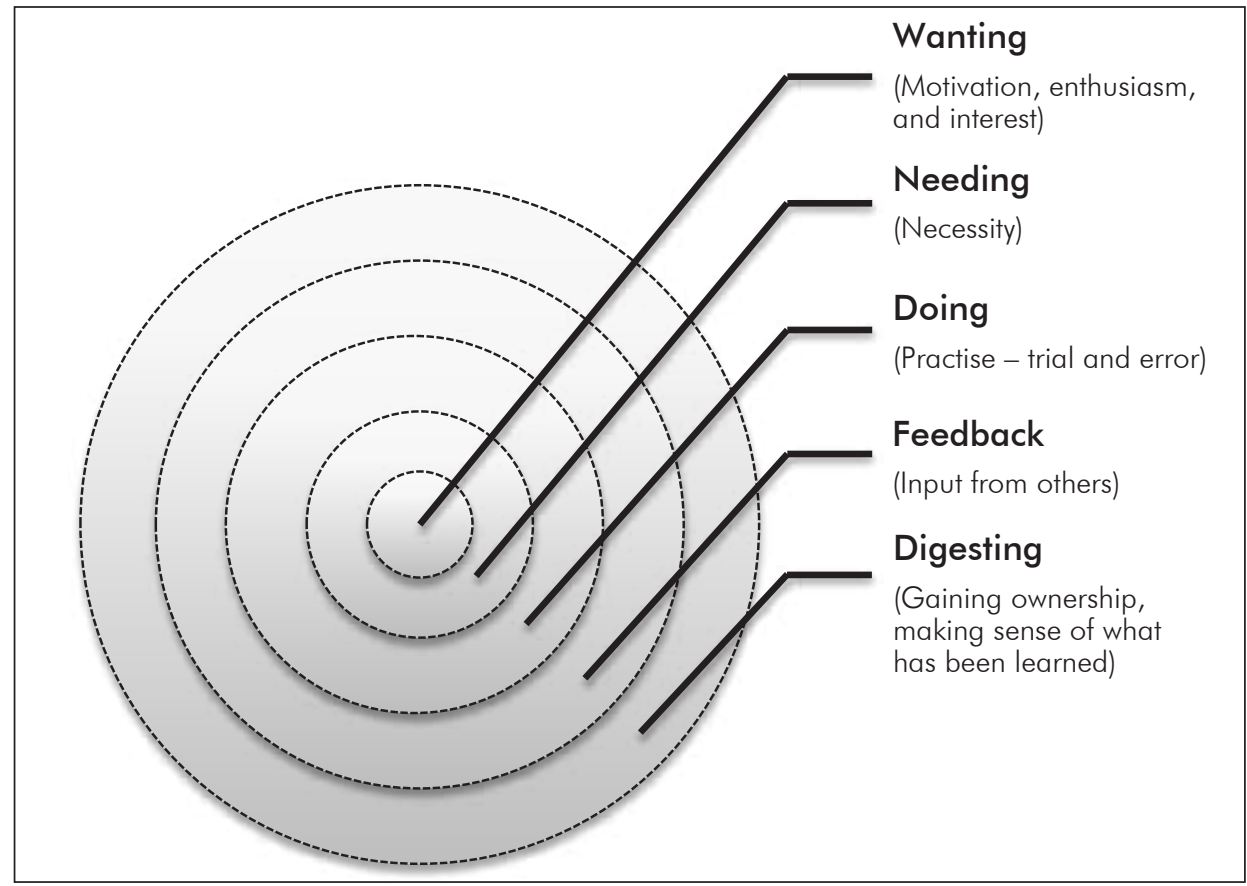

FIGURE 17.1 Race's 'spreading ripples' model of learning (adapted from Race 2001:28)

Figure 17.1 shows that wanting/needing to learn is placed in the centre of things as it is a powerful source providing the energy that makes a student want to learn something in the first place (Race 2001:9). This leads to the belief that learning can be initiated by the bounce-back ripples through doing, making sense, providing feedback and understanding. The problem that we face is that assessment is a sensitive issue in that it is closely integrated with motivation (Harlen 2006:62; Harris 2007:259). Bloxham and Boyd (2008:20) argue that most students experience some stress if lecturers talk about assessment and, depending on the way it is implemented, it can unfortunately often work against rather than for learning. When students begin to compare themselves with others, assessment becomes tied up with a social and emotional experience that can influence their motivation and self-esteem. Students who believe that they lack ability will become unmotivated to learn as they fear failing. They will "retire hurt" and avoid further effort in learning because of the belief that their efforts will only result in disappointment (Black \& Wiliam 2001:6).

Integrating assessment into the 'doing' ripple involves a much broader perspective than what Broadfoot (2007:1 19) coins as the "conventional empty vessel perspective". Broadfoot explains that assessment does not imply that a lecturer merely deposits knowledge in the student's mind and then checks whether the student is able to retrieve such knowledge by testing lower-order cognitive skills. Assessment should rather engage students in worthwhile educational experiences by providing them with opportunities 
to take an active role in learning, to master autonomy and to develop self-efficacy (Cauley \& McMillan 2010:6; Garrison \& Vaughan 2008: 16; Race 2001:12).

Gijbels and Dochy (2006:399) argue that successful functioning in society demands authentic assessment methods in which students are given the opportunity to apply their knowledge in authentic representations of real-life problems and to develop conceptual understanding. Harris (2008:59), however, points out that physical participation does not guarantee students' cognitive engagement. Linnenbrink and Pintrich (2003:124) contend that learning should not just be 'hands on' but also 'minds on', arguing that students ought to think deeply, critically and creatively about the content and should know how to use a variety of strategies to increase their understanding of the learning material. This process involves the students' perceptions of academic competency and may guide their behaviour (Walker \& Greene 2009:463). Here, meta-cognitive skills play an important role as they are necessary aspects of reflecting on actions and regulating learning.

Gaining understanding or making sense of what is being learned is a key factor underpinning successful learning and forms an important aspect of the 'digesting' ripple. Race (2005:26) defines this important process as digesting or "getting your head around it". Digesting knowledge involves more than observation or the mere reflection of information; it rather refers to a sense of ownership (Race 2007:9). A central feature of the knowledge-construction process involves the idea that students take responsibility for their own meaning making where nobody else can do it for them. Digesting can therefore be described as an intentional action when students identify the important aspects of what must be learnt and discard what is unimportant. This action involves time to reflect and to communicate own progress while linking it to the feedback, doing and learning (Race 2007:248).

Following from these points, it can be argued that programmes should not only provide students with opportunities to experience success but also with opportunities where feedback can guide them as to what to improve. Feedback to students comes from different directions, which can cause the ripple to move back into the centre and create some motivation. It furthermore has the potential to advance student learning because it allows students to recognise areas of deficiency in their knowledge and helps them to plan for future learning (Crisp 2007:572; Nicol \& Macfarlane-Dick 2006:200; Perera, Lee, Win, Perera \& Wijesuriya 2008:395; Rodgers 2006:219). Feedback can thus stimulate the whole learning ripple and, ultimately, it may encourage the 'digesting' stage. It is no wonder that scholars often refer to feedback as the oil that makes the assessment engine run, or as Pickford and Brown (2006:13) put it, feedback "lubricates the cogs of understanding".

Scrutiny of Race's 'spreading ripples' model revealed the importance of providing opportunities in the curriculum to achieve the following distinct purposes of assessment: assessment should inspire students by encouraging engagement in learning, it should 
provide opportunities to think critically and to reflect over time, and it should entail meaningful feedback.

\section{THE QUALITATIVE INQUIRY}

Brown, Mclnerney and Liem (2009:4) maintain that much attention has been paid to the ways in which assessment can be used to improve learning as opposed to simply being used to evaluate learning. Although the idea of student-centred learning makes sense, these authors find it strange that so little attention has been focused on the perspectives of students - the very people who are supposed to do the actual learning. Solis $(2003: 10,11)$ agrees that student perspectives are often overlooked and that researchers lack students' input when investigating assessment. Bearing the foregoing in mind, students' perspectives might be considered when planning a curriculum-renewal endeavour. The interpretive qualitative approach thus allowed me to explore how participants make meaning of their assessment experiences in the Life Skills module and to discover meaningful patterns from these perspectives. The main categories that emerged during the course of the coding process are the meaning of assessment, engagement in learning, and feedback.

\section{Meaning of assessment}

Written and oral examinations have existed for centuries - from the early Chinese examinations, through public presentations by students of Aristotle, to the universal examinations of the past century (Earl 2003:5). Braskamp (2005:75) believes the word 'assessment' to be derived from an idea important to educators: one of sitting down beside or together, these in their turn derived from the Latin words ad and sedere, which brings to mind verbs such as to engage, to involve, to interact, to share or to trust. From the above definition one can interpret the idea of 'sitting beside' in the Life Skills classroom as a communication process between the student, the lecturer and the curriculum designer. Such a communication process implies that if lecturers perhaps know how students feel and experience assessment, surely then they can be helped to make the connection between the purpose of the assessment and the assessment task.

Some participants described the examination experience as "definitely negative", while others regarded it to be an effective assessment method:

We want to write exams.

Yes, an exam is effective.

In contrast, Jansen (rector of the University of the Free State) questioned the validity of a formal examination as the only assessment method when he recently stated that formal examinations place too much pressure on students and proposed a system in which students should be evaluated throughout the year by using a variety of methods to assess academic proficiency (Coetzee 2009:11). Maclellan (2004:314) elaborates by arguing that assessment should be implemented as an educational tool that helps 
students to take an independent, active role in their learning and develops their cognitive abilities of thinking, reasoning, planning and decision making in the service of solving real-life problems. One wonders whether formal examinations always fulfil this role. It seemed necessary to probe whether participants' perspectives of examinations as 'effective methods' reflected this particular understanding. A closer look at the reasons behind the statements revealed that some participants may indeed have interpreted the 'effectiveness' of examinations in terms of a time-management tool, rather than in terms of the conceptual understanding of the content. One participant explained:

I uhm ... I uh had like 11 subjects this semester and to put a lot of effort into every single lecture takes a lot of time, and in a term you don't really have that, where in the exam you can focus [on] only one...

Other comments furthermore lead one to believe that some participants regarded studying during examinations as the mere regurgitation of facts and not necessarily as an educational tool for self-regulated learning, for example:

You only learn nonsense. And you forget it.

But you often also learn like a parrot.

This then begs the question how assessment can be implemented in a programme to entail more than the mere memorisation and reproduction of factual knowledge. In attempting to answer this question, the next section will explore how assessment can be integrated into Race's 'spreading ripples' model of learning by focusing on motivational, behavioural and cognitive engagement and thus preparing the teacher for the school classroom.

\section{Engagement in learning}

According to Crick (2007:137), the education system needs to foster flexible learners who are able to extend their learning and understanding beyond the classroom. This principle was implemented by exposing students to unfamiliar assessment opportunities through blended learning, a research project and community service. A number of issues emerged when the data were analysed. Some students pointed out some advantages of mobile learning, for example having the flexibility to have access anytime and anywhere, and being able to work independently and to receive immediate feedback. Others complained about the cost, the small screen and technological problems related to incompatible phones. Mobile learning and assessment activities, however, forced students to engage in the learning process before, during or sometimes at the end of a lecture, as one participant indicated: "This forced me to spend time going through my work before class."

Blackboard assessment activities provided students with opportunities to explore ideas, to rectify mistakes, to question perceptions and to construct meaning from information. This developmental value of formative assessment is highlighted in the following 
remark from a participant explaining that students could go back and improve before receiving a final mark: "There are also enough activities to increase your semester mark and you not only have to do rote learning, but also to apply the knowledge." It also appeared that students placed high value on learning while in a real classroom context. The following comments captured this view:

I think ... because it puts you in that situation ... Because it is easy just to read in a book what is out there, but if you physically see it, then you can realise: OK this needs to be done and OK then we can do this and do that.

It's not just about knowledge. You learn to use knowledge and skills. If you land in a situation, you have to learn to handle it; you have to be able to apply it.

I think it better teaches you to think on your feet.

Students were presented not only with online case studies to apply the 'knowing' and the 'doing' simultaneously, but also with authentic learning experiences in the form of a research project and a community service project. These assignments demanded higher-order thinking such as diagnosing, problem solving, explaining and decision making. The integration between cognitive and behavioural engagement became clear when a student noted that "you are physically there ... and you realise this needs to be done".

Not only did the community project expose students to authentic experience but they were also given an opportunity to engage in problem solving, teamwork, communication and self-regulated learning as they had to plan and organise the project, work together and write a report by integrating a literature review with the practical application. Some students included a photo-shop CD to explain the project visually, meaning that technological skills were also stimulated. During the focus-group discussions the informants were asked whether they thought that Life Skills education had in fact changed some of their attitudes. Although some students answered this question, they were not convinced that Life Skills had influenced their attitudes regarding certain aspects. However, at the end of the second semester students clearly indicated that personal growth had occurred. One student said:

Giving is certainly one of the most enriching experiences. No amount of money can buy such experiences. Meaning something to your community engenders personal growth. Thank you for this opportunity to make a difference.

Participants' comments indicated that involvement in a real-life community would indeed motivate learning as students became highly motivated when they realised that their efforts could make a difference. Following from these observations one can state that assessment activities should be considered carefully when planning a curriculum. Assessment activities can therefore be implemented to extend student learning beyond the higher education classroom into a school classroom in which personal growth and the development of a sense of caring towards others are fostered. 


\section{Feedback}

Research emphasises that feedback has the potential to advance student learning because it allows students to recognise areas of deficiency in their knowledge and helps them to plan for future learning (Crisp 2007:572; Nicol \& Macfarlane-Dick 2006:200; Perera et al 2008:395; Rodgers 2006:219). Although the expectation is that feedback should enhance student learning, it often seems as if students focus on their marks only and ignore the lecturer's feedback, especially if they interpret the feedback as being negative. Meyer (2009:215) explains that learners in South African schools often experience summative assessment as the dominant mode of assessment and therefore students at university are often unable to recognise the value of formative feedback and "may even be traumatized by the presence of so much ink on the page". Feedback can thus, on the one hand, empower the student; on the other, it can impede learning.

Students need prompt feedback because the longer the delay, the less likely it is that they will find it useful or be able to apply the suggestions (Freeman \& Lewis 1998:49). Research emphasises that the most effective feedback is immediate, specific and according to specific criteria (Organisation for Economic Co-operation and Development 2005:3). One can thus argue that frequent and timely feedback increases motivation and tends to motivate students to engage in learning. Participants articulated this idea in the following responses:

Now you have to balance the time of feedback. Timing of feedback - which is so crucial.

So I think the most important thing for me is that it must be given as quickly as possible.

The value of written feedback to students lies in their being able to read both the diagnosis of their errors and the suggestions on how to improve. They can always go back to reread the feedback and reflect on it again. Whereas written feedback can often be cryptic, oral feedback offers an opportunity of elaborating more in the form of detailed comments. Here, the feedback language can play a critical role. The challenge however lies in the purpose of the feedback in that the feedback must be educative. It is possible to argue that the focus should neither be on whether the feedback is written, or oral, or on the amount of commentary, but rather on what the students do with the feedback. The idea that feedback should be an indication of encouragement is reflected in the following remarks:

And this means even more to me ... And that meant a lot to me because I studied hard and even now that I did not get a distinction, I still tried and it was still appreciated.

Then I feel rather good. Then I at least think someone is noticing your hard work.

The nature of the feedback is however not as important as the fact that the students understand and use the feedback and moreover believe that the feedback will tell 
them how to improve. It is evident that students will tend to be more inspired to learn if they believe that the feedback can help to improve their performance. It is important, therefore, that students recognise the purpose of the feedback and that they interpret and apply the suggestions in order to close the gap between their current level of performance and the expected learning objective. This idea is reflected in Harris's idea (2007:257) that students need to know precisely what and how they will be assessed in order to be successful. Participants agreed that feedback had to be given in accordance with the assessment criteria. In addition to this idea, one could make a case that the focus should rather be on feeding forward instead of only feeding back. 'Feed-forward' can be explained as providing the student with the ability to close the gap between the areas of deficiency and how to remedy these. Through this act students monitor their learning process, which will enable them to become reflective, self-directed and self-regulated learners. In other words, it is important that students distinguish between feedback and feed-forward and not merely focus on what has already been done in order consciously to build upon their strengths as the work progresses. In the final analysis, the idea emerges that feedback will only be effective if students pay attention to it, believe it and use it.

\section{IMPLICATIONS OF THE STUDY}

If we therefore consider assessment to be inextricably part of the curriculum and to be at the centre of a student's learning experience, it is interesting to note, from the data analysed, that in reality lecturers and students can indeed have differing understandings of the role of assessment in learning. It follows that lecturers need to be mindful of how students feel about and experience assessment when designing assessment activities as part of a curriculum: first, to ensure a connection between the purpose of the assessment and the assessment task itself; and, second, to prepare students for their future professional roles.

Perhaps a shift in thinking about assessment is required at the interface between teaching (lecturing) and learning so as not to get fixated on the assessment method per se but always to bear in mind the underpinning purpose - namely that of promoting student learning. Based on Race's 'spreading ripples' learning model, this study has highlighted how assessment and learning can co-exist, complement and support each other in the Life Skills classroom. It therefore seems as if one ought to shift the focus from the divide between assessment for and assessment of learning to one that finds ways to integrate assessment into learning while empowering students to move forward in their learning. Perhaps, by using these methods in tandem in the Life Skills classroom one can optimally promote student learning.

The findings further indicated that a hands-on experience may lead to greater in-depth understanding. In this regard one participant observed: "This learning experience made me realise how important Life Skills is in the Foundation Phase." This idea emphasised the importance of authentic, real-life situations in a curriculum to provide students with 
opportunities to learn by doing. This not only develops better-educated students, but it may also provide opportunities for personal development, as the following suggests: "At the end of the day the project meant more to me personally than for instance, the marks that I am going to get for it."

It is evident that it is not the feedback itself that will improve learning, but the way students understand what to do with the feedback that might motivate them to be engaged in the learning process. It is suggested that a curriculum should provide students with opportunities to interpret feedback as feed-forward; in other words, to focus on what has already been done and consciously to build upon their strengths as they progress. Thus, for feedback to be effective in the Life Skills classroom, it needs to be timely, meaningful and also provide specific suggestions about problems - clear suggestions that can focus students' attention on rectifying mistakes. A central idea here is the concept of feed-forward where the feedback has a forward-looking purpose with a positive focus on subsequent steps for improvement. This idea implies that feedback should enable students to close the gap between areas of deficiency with ways to improve.

\section{CONCLUSION}

In this chapter some possibilities have been explored for curriculum inquiry to enhance learning in one higher education classroom. The findings of my inquiry hold promise for lecturers to rethink classroom practices when approaching curriculum renewal from the angle of assessment. Based on the findings, I want to emphasise a number of critical factors:

First, the findings from the inquiry suggest that students' perspectives can be useful in planning assessment practices and thus also course renewal. However, a shared understanding of the purpose and effects is required so that students will clearly know where they are heading with their learning.

Second, in addressing the value of assessment in the Life Skills classroom, assessment arguably plays a key role - both in fostering learning and in the certification of students. It seems evident that one can easily become entangled in assessment issues and lose sight of the real purpose of assessment in a single course and in a specific classroom. The core mission of designing assessment activities therefore involves careful consideration of the students' learning tasks. It is the lecturer's sole responsibility to plan assessment methods whereby students will be able to demonstrate their learning and to help them to have developed a well-rounded set of abilities by the time they graduate. These abilities include both intellectual and personal development. This idea in turn implies that both formative and summative assessment can be implemented as complementary and overlapping methods - in this case, in the Life Skills classroom the aim being to benefit the quality of student learning. 
Third, if the focus is on student learning, this means that students need to be involved in authentic situations in which they have to perform real-world tasks that demonstrate meaningful application of essential knowledge in their acquired skills. There is little doubt that assessment experiences allow students to arrive at conclusions about themselves based on the information they receive from the assessment. In my inquiry, it was apparent that assessment practices must provide students with opportunities to learn and develop through motivational, cognitive and behavioural engagement that allows them to use their knowledge and skills in real-life situations.

Fourth, bearing this latter idea in mind, the implication is therefore that assessment should be used as a tool that increases students' faith in themselves as successful learners. Central to this idea is Race's 'spreading ripples' model of learning which suggests that learning can be initiated by the bounced-back ripples through doing, making sense, feedback and understanding. It should therefore be vitally important to consider these different elements during the assessment process so as to promote student motivation, engagement and self-regulation.

The above-mentioned four ideas frame this chapter's message, namely that an inquiry into assessment theory and practices can influence students' engagement in the learning process. Therefore, when lecturers plan their assessment activities, they must remember that the primary purpose of assessment should be to serve student learning.

\section{REFERENCES}

Albon R. 2006. A case study of the integration of self, peer, and group assessment in a core first-year educational psychology unit through flexible delivery implementation. In: TS Roberts (ed). Self, peer and group assessment in e-learning. London: Information Science Publishing. 101-141.

Basit TN. 2003. Manual or electronic? The role of coding in qualitative data analysis. Educational Research, 45(2):143-154.

Baxter P \& Jack S. 2008. Qualitative case study methodology: Study design and implementation for novice researchers. The Qualitative Report, 13(4):544-559.

Beets P. 2009. Towards integrated assessment in South African higher education. In: E Bitzer (ed). Higher Education in South Africa - A scholarly look behind the scenes. Stellenbosch: SUN MeDIA. 183-203.

Black P \& Wiliam D. 1998. Assessment and classroom learning. Assessment in Education, Principles, Policy \& Practice. March 1998, 5(1): 1-54. [Retrieved 3 March 2010] http://0-web.ebshcochost.com.wagtail.vovs.ac.za

Black P \& Wiliam D. 2001. Inside the black box: Raising standards through classroom assessment. King's College, London School of Education. [Retrieved 20 December 2009] www.education.typepad.co.uk/files/blackbox- 1 pdf

Bloxham S \& Boyd P. 2008. Developing effective assessment in higher education: A practical guide. London: McGraw-Hill. 
Braskamp L. 2005. Advice to deans: Assessing faculty work by "sitting beside". Education for Health, 18(1):74-79.

Broadfoot P. 2007. An introduction to assessment. New York: Continuum.

Brown GTL, Mclnerney DM \& Liem GAD. 2009. Student perspectives of assessment: Considering what assessment means to learners. In: DM Mclnerney, GTL Brown \& GAD Liem (eds). Student perspectives on assessment: What students can tell us about assessment for learning. New York: Information Age. 1-24.

Carl AE. 2009. Teacher empowerment through curriculum development: Theory into practice. 3rd Edition. Landsdowne: Juta.

Cauley K \& McMillan JH. 2010. Formative assessment techniques to support student motivation and achievement. The Clearing House, 83(1):1-6.

Coetzee G. 2009. Formele eksamens dalk iets van die verlede. Volksblad, 4 November 2009. [Retrieved 6 November 2009] www.volksblad.com/.../Formele-eksamens-dalk-iets-vandie-verlede-

Cowdroy R \& Williams A. 2007. Aligning teaching and assessment: The key to greatly improved graduate quality and sustainable teaching efficiency. In: S Frankland (ed). Enhancing teaching and learning through assessment. Dordrecht: Springer. 88-97.

Crawford HK, Leybourne ML \& Arnott A. 2000. How we ensured rigour in a multi-site, multi-discipline, multi-researcher study. Forum: Qualitative Sozialforschung/Forum: Qualitative Social Research, 1(1):12. [Retrieved 26 June 2010] http://nbn-resolving.de/ urn:nbn:de:0114-fqs0001125

Crick RD. 2007. Learning how to learn: The dynamic assessment of learning power. The Curriculum Journal, 18(2):135-153.

Crisp BR. 2007. Is it worth the effort? How feedback influences students' subsequent submission of assessable work. Assessment \& Evaluation in Higher Education, 32(5):571-581.

Earl LRJ. 2003. Assessment as learning: Using classroom assessment to maximize student learning. London: Sage.

Flick U. 2004. Triangulation in qualitative research. In: U Flick, E von Kardorff \& I Steinke (eds). A companion to qualitative research. London: Sage. 178-202.

Flick U. 2009. An introduction to qualitative research. 4th Edition. London: Sage.

Fraenkel JR \& Wallen NE. 2008. How to design and evaluate research in education. 7th Edition. New York: McGraw-Hill.

Freeman R \& Lewis R. 1998. Planning and implementing assessment. London: Kogan.

Garrison DR \& Vaughan ND. 2008. Blended learning in higher education: Framework, principles, and guidelines. San Francisco, CA: Wiley.

Gijbels D \& Dochy F. 2006. Students' assessment preferences and approaches to learning: Can formative assessment make a difference? Educational Studies, 32(4):399-409.

Harlen W. 2006. The role of assessment in developing motivation for learning. In: J Gardner (ed). Assessment and learning. London: Sage. 61-81. 
Harris LR. 2007. Employing formative assessment in the classroom. Sage Publications, 10(3):249-260. [Retrieved 12 December 2009] http://imp.sagepub.com/cgi/content/ abstract/10/3/249

Harris LR. 2008. A phenomenographic investigation of teacher conceptions of student engagement in learning. The Australian Educational Researcher, 35(1):57-78.

Henning E, Van Rensburg W \& Smit B. 2004. Finding your way in qualitative research. Pretoria: Van Schaik.

James R, Mclnnis C \& Devlin M. 2002. Assessing learning in Australian universities. [Retrieved 18 March 2001] www.cshe.unimelb.edu.au/assessinglearning

Kvale S. 1996. Interviews: An introduction to qualitative research interviewing. London: Sage.

Lewis J \& Ritchie J. 2003. Generalising from qualitative research. In: J Ritchie \& J Lewis (eds). Qualitative research practice: A guide for social science students and researchers. London: Sage. 263-286.

Lincoln YS \& Guba EG. 1985. Naturalistic inquiry. London: Sage.

Linnenbrink EA \& Pintrich PR. 2003. The role of self-efficacy beliefs in student engagement and learning in the classroom. Reading \& Writing Quarterly, 19:1 19-137.

Maclellan E. 2004. How convincing is alternative assessment for use in higher education? Assessment \& Evaluation in Higher Education, 29(3):31 1-321.

Marriott P. 2009. Students' evaluation of the use of online summative assessment on an undergraduate financial accounting module. British Journal of Educational Technology, 40(2):237-254 .

Meyer WH. 2009. When you just get a mark and a nasty comment, what's that called? Summative assessment: Creating an enabling environment for formative assessment. South African Linguistics and Applied Language Studies, 27(2):215-228.

Miles MB \& Huberman AM. 1994. Qualitative data analysis: An expanded sourcebook. London: Sage.

Nicol D \& Macfarlane-Dick D. 2006. Formative assessment and self-regulated learning: A model and seven principles of good feedback practice. Studies in Higher Education, $31(2): 199-218$.

Organisation for Economic Co-operation and Development (OECD). 2005. Formative assessment: Improving learning in secondary classrooms. Policy brief. [Retrieved 13 June 2010] www.oecd.org/dataoecd/19/31/3561078

Perera J, Lee N, Win K, Perera J \& Wijesuriya L. 2008. Formative feedback to students: The mismatch between faculty perceptions and student expectations. Medical Teacher, 30:395-399.

Perone J \& Tucker L. 2003. An exploration of triangulation of methodologies: Quantitative and qualitative methodology fusion in an investigation of perceptions of transit safety. Centre for Urban Transportation Research, University of South Florida. [Retrieved 1 July 2010] www.dot.state.fl.us/research-center/...Proj/.../FDOT-BC137-22.pdf

Pickford R \& Brown S. 2006. Assessing skills and practice. London: Routledge. 
PART THREE • METHODS FOR INTERROGATING, REVISIONING AND IMPLEMENTING CURRICULUM CHANGE

Race P. 2001. The lecturer's toolkit: A resource for developing assessment, learning and teaching. 2nd Edition. London: Routledge.

Race P. 2005. Making learning happen: A guide for post-compulsory education. London: Sage.

Race P. 2007. The lecturer's toolkit: A resource for developing assessment, learning and teaching. 3rd Edition. London: Routledge.

Race P \& Pickford R. 2007. Making teaching work: Teaching smarter in post-compulsory education. London: Sage.

Robson C. 1993. Real world research: A resource for social scientists and practitionerresearchers. Oxford: Blackwell.

Rodgers CR. 2006. Attending to student voice: The impact of descriptive feedback on learning and teaching. Curriculum Inquiry, 36(2):219-236.

Ross A. 2000. Curriculum: Construction and critique. London: Falmer Press.

Shay S. 2008. Beyond social constructivist perspectives on assessment: The centring of knowledge. Teaching in Higher Education, 13(5):595-605.

Shay S \& Jawitz J. 2005. Assessment and the quality of educational programmes: What constitutes evidence? Perspectives in Education, 23(1):103-112.

Solis M. 2003. Evaluations vs. assessment: The student's perspective on the student evaluation process. Culture, Society \& Praxis, 2(1):7-22.

Stefani L. 2009. Planning, teaching and learning: Curriculum design and development. In: H Fry, S Ketteridge \& S Marshall (eds). A handbook for learning and teaching in higher education: Enhancing academic practice. New York: Routledge. 40-58.

Walker CO \& Greene BA. 2009. The relations between student motivational beliefs and cognitive engagement in high school. The Journal of Educational Research, 102(6):463-471.

Wellington J. 2000. Educational research: Contemporary issues and practical approaches. London: Continuum. 